\title{
Media Pembelajaran Digital Berbasis Macromedia Flash untuk Mata Pelajaran Fisika tingkat SMP
}

\author{
Macromedia Flash-based Digital Teaching Media for Junior High School Physics
}

Andinusa Rahmandhika
Heni Hendaryati
Ary Dwi Astuti*
Department of Mechanical
Engineering,
Muhammadiyah Malang, Malang,
East Java, Indonesia

email: arydwi@umm.ac.id
Kata Kunci
Digital
Fisika
Macromedia Flash
Media pembelajaran
Keywords:
Digital
Physics
Macromedia Flash
Teaching Media
Accepted: October 2021
Published: January 2022

\begin{abstract}
Abstrak
Pengembangan inovasi pembelajaran dilakukan untuk membentuk atmosfter pembelajaran yang menyenangkan, kreatif, dan aktif bagi siswa sehingga siswa bisa meningkatkan capaiannya. Media pembelajaran yang bisa mendukung kreativitas dan pemikiran kritis siswa diperlukan sebagai media yang bisa membantu guru menyampaikan materi. Adanya Teknologi Informasi dan Komunikasi (TIK) juga bisa dimanfaatkan untuk membuat media pembelajaran yang bisa meningkatkan motivasi belajar siswa. Pengabdian ini bertujuan untuk memberikan pendampingan pada pemanfaatan software Macromedia Flash untuk membuat aplikasi media pembelajaran Fisika SMP Muhammadiyah 6 Dau Malang. Instrumen yang digunakan untuk mengetahuai situasi pembelajaran adalah wawancara yang dilakukan dengan guru. Dari wawancara yang dilakukan, diketahui bahwa siswa sangat termotivasi belajar ketika mereka praktikum, namun tidak pada saat pembelajaran di kelas. Pengabdian ini menghasilkan aplikasi media pembelajaran atraktif yang dibuat dengan menggunakan Macromedia Flash.
\end{abstract}

\begin{abstract}
The development and improvement of teaching innovation aim to bring an enjoyable, joyful, active, and creative atmosphere for students to increase and improve their achievement. Teaching media that support student's creativity and critical thinking are needed to facilitate teachers presenting the learning material. Information and Communication Technology (ICT) can introduce media to increase students' learning motivation. This program instructs teachers in using Macromedia Flash software to create learning media applications for the physics units. It was conducted in SMP Muhammadiyah 6 Dau Malang. An instrument to observe the teaching situation is an interview with the teacher. Information from the interview, students have high motivation during their practice in the lab, but the opposite occurs in the class. The result of this program is an attractive teaching media application created by using Macromedia Flash software.
\end{abstract}

(C) 2022 Andinusa Rahmandhika, Heni Hendaryati, Ary Dwi Astuti. Published by Institute for Research and Community Services Universitas Muhammadiyah Palangkaraya. This is Open Access article under the CC-BYSA License (http://creativecommons.org/licenses/by-sa/4.0/). https://doi.org/10.33084/pengabdianmu.v7i1.2295

\section{PENDAHULUAN}

Inovasi pembelajaran terus dikembangkan untuk membentuk suasana belajar yang menyenangkan, kreatif, dan aktif sehingga bisa meningkatkan pemahaman dan hasil belajar siswa. Dalam melakukan inovasi pembelajaran, guru harus kreatif dalam mempersiapkan model, metode, bahan ajar, instrumen, dan media pembelajaran yang bisa mendukung pemikiran kritis siswa. Proses belajar mengajar yang direncanakan dan dipersiapkan oleh guru harus bisa memberikan keterampilan berpikir tingkat tinggi untuk siswa, Higher Order Thinking Skills (HOTS). Pengembangan HOTS siswa sudah dilakukan mulai dari pendidikan dasar hingga tingkat sekolah menengah melalui instrumen berupa soal latihan atau lembar kerja siswa (Husnawati et al., 2019; Rofiah et al., 2018; Sarwinda \& Meilana, 2019). Instrumen tersebut digunakan guru untuk mengembangkan ranah kognitif siswa untuk meningkatkan pengetahuan, pemahaman, melakukan analisa, dan melakukan deduksi. Metode pengajaran dan model pembelajaran yang digunakan guru juga bisa mendukung pengembangan HOTS siswa melalui materi pelajaran yang diberikan dan media pembelajaran yang digunakan. 
Perkembangan media pembelajaran sekarang ini banyak didukung oleh perkembangan teknologi. Penguasaan guru pada teknologi akan memberikan wawasan yang lebih luas pada siswa saat mereka berada pada proses belajar mengajar. Penggunaan teknologi informasi dan komunikasi (TIK) sebenarnya bisa mempermudah guru memotivasi siswa untuk belajar melalui presentasi animatif yang disajikan (Siahaan, 2015). Software desain dan grafis bisa mendukung pembuatan animasi yang menarik baik untuk presentasi ataupun simulasi sehingga bisa menimbulkan suasana pembelajaran yang interaktif. Jaringan internet juga bisa memberikan banyak referensi bagi guru untuk menyusun rencana pembelajaran mulai dari metode pembelajaran, bahan ajar, instrumen penilaian, dan media pembelajaran. Namun demikian, TIK ini masih belum banyak dikuasai oleh sebagian besar guru karena banyak aplikasi dan fitur aplikasi yang harus dikuasai. Karena itu, pelatihan dan pembimbingan dilakukan untuk mengembangkan keterampilan guru dalam menguasai TIK (Budiarto et al., 2016; Muthmainnah et al., 2017; Nurdewanto et al., 2018; Tekege, 2017).

Macromedia Flash merupakan salah satu software animasi yang bisa digunakan sebagai media pembelajaran selain PowerPoint. Software ini memberikan kemudahan bagi penggunanya untuk membuat gambar dan teks dengan pewarnaan dan efek yang menarik. Animasi gerak untuk objek gambar dan teks bisa dilakukan dengan memberikan perintah motion. Untuk pembuatan animasi yang kompleks, pengguna bisa menggunakan fitur actionscript pada Macromedia Flash. Fitur-fitur yang dimiliki Macromedia Flash bisa membantu guru untuk menciptakan pembelajaran interaktif melalui animasi. Selain itu, guru juga bisa membuat aplikasi instrumen penilaian. Aplikasi yang dihasilkan dari Macromedia Flash juga bisa ditampilkan atau dijalankan secara online sehingga hasil penilaian siswa bisa didapatkan secara real-time.

Pengembangan keterampilan guru dalam membuat media pembelajaran dengan Macromedia Flash dilakukan agar guru bisa menciptakan media pembelajaran yang interaktif sehingga proses pembelajaran bisa berjalan dengan menyenangkan dan aktif. Pelatihan dan pendampingan untuk guru ditujukan untuk meningkatkan penguasaan dan pemahaman guru terhadap Macromedia Flash (Lubis \& Siregar, 2020; Nugraheny et al., 2018; Rahayu \& Widyawati, 2019; Rahmi et al., 2019; Umbara et al., 2019). Dari pengabdian yang telah dilakukan dengan mengadakan pelatihan dan pendampingan pada guru, pengabdian ini akan menunjukkan pemanfaatan aplikasi animatif pada laptop, atau personal computer (PC) yang diciptakan dari Macromedia Flash. Pelaksanaannya ditujukan untuk membantu guru menggunakan media pembelajaran yang fleksibel untuk metode pengajaran di kelas dan pengajaran jarak jauh mengingat kondisi pendidikan sekarang ini yang memerlukan pelaksanaannya secara online karena pandemi COVID-19.

\section{METODE}

Pelaksanaan pengabdian ini dimulai dari analisa situasi yang dihadapi mitra, pengampu mata pelajaran Fisika SMP Muhammadiyah 6 Dau Malang. Analisa situasi dilakukan dengan melakukan wawancara dengan pengampu mata pelajaran Fisika kelas 7, 8, dan 9 untuk mengetahui permasalahan yang dihadapi oleh guru. Perencanaan kegiatan pengabdian dilakukan dengan menyesuaikan Kurikulum 2013 dan RPP dan Promes yang dibuat oleh guru. Pendalaman konsep IPA Fisika dilakukan untuk menyusun materi dan soal latihan dengan menggunakan Macromedia Flash.

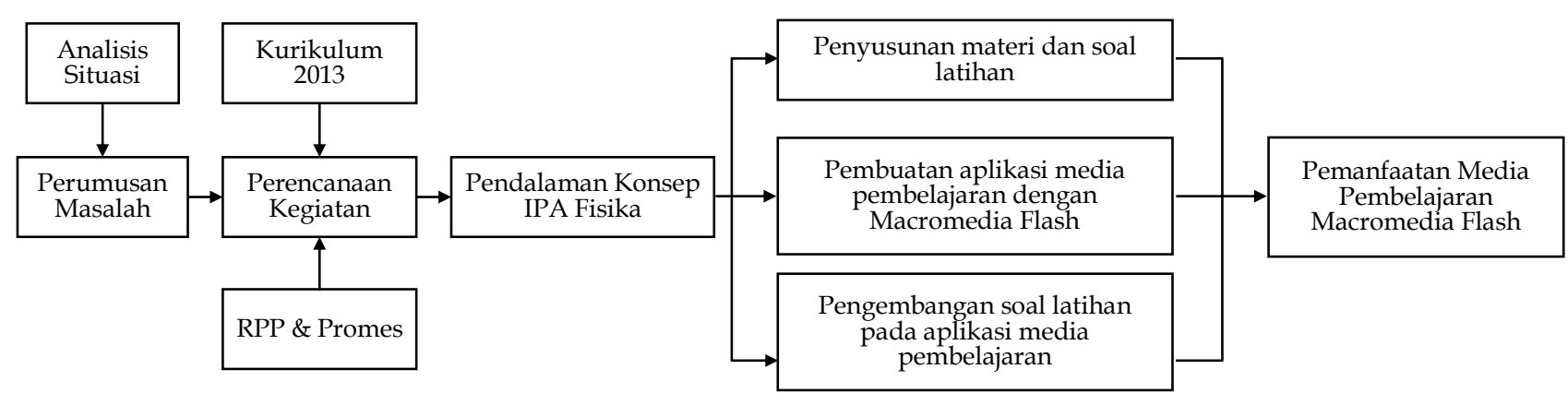

Gambar 1. Alur pelaksanaan pengabdian 
Pengembangan soal latihan pada aplikasi media pembelajaran dilakukan untuk menambah database instrumen penilaian siswa. Setiap bagian soal disusun dari soal yang paling mudah ke soal yang tersulit.

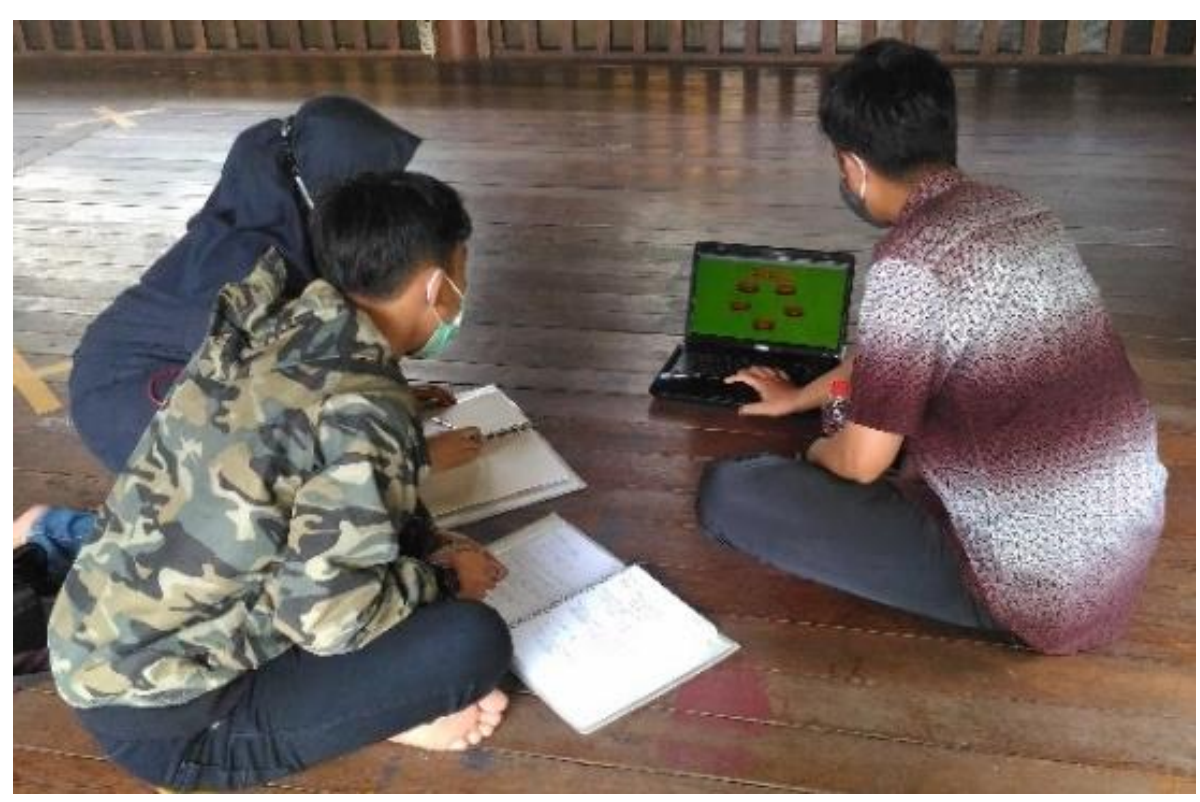

Gambar 2. Penyusunan materi dan pembuatan media pembelajaran dengan Macromedia Flash

\section{HASIL DAN PEMBAHASAN}

Pelaksanaan pengabdian diawali dengan melakukan wawancara dengan guru untuk mengetahui situasi pembelajaran yang terjadi. Ada tujuh pertanyaan yang diajukan pengabdi kepada guru. Ketujuh pertanyaan tersebut menggali informasi proses belajar mengajar, metode, dan media pembelajaran yang digunakan oleh guru. Tahap selanjutnya pengabdi memperkenalkan Macromedia Flash kepada guru. Macromedia Flash merupakan software animasi dan grafis yang bisa digunakan untuk membuat aplikasi interaktif. Software ini memberikan fitur efek yang menarik sehingga pengguna bisa membuat gambar bergerak. Software ini bisa dimanfaatkan untuk membuat aplikasi sebagai media pembelajaran.

Tutorial dan modul diberikan kepada guru untuk mulai membuat presentasi materi dengan menggunakan Macromedia Flash. Guru diajarkan untuk membuat bentuk, simbol, dan tulisan yang menarik. Pendampingan dilakukan secara bertahap mengingat proses pembuatan media pembelajaran dengan Macromedia Flash memerlukan detail, tombol dan efek. Pembuatan tombol bisa dilakukan dengan menggunakan aplikasi pendukung, bisa PowerPoint, Word, atau Photoshop. Pembuatan tulisan yang menarik juga dilakukan untuk membuat cover atau halaman depan aplikasi. Komponen lain yang bisa membuat tampilan aplikasi lebih menarik juga bisa ditelusuri dari mesin pencarian/browser.

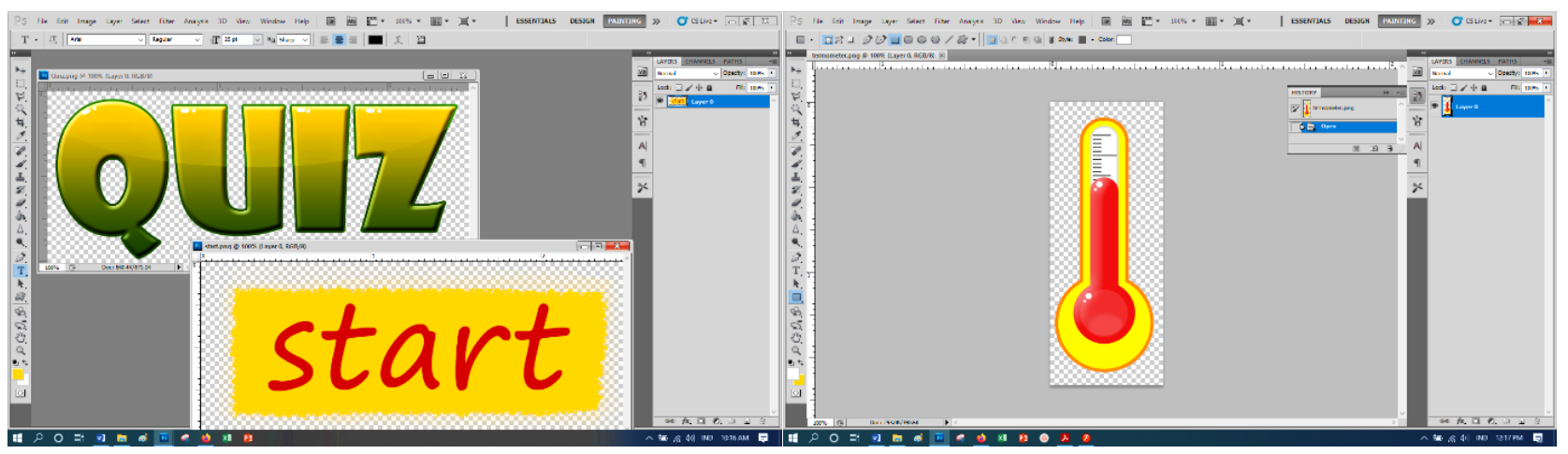

Gambar 3. Proses pembuatan karakter dengan bantuan Photoshop 
mulai
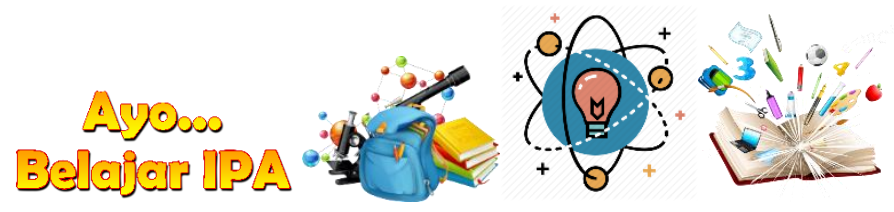

Gambar 4. Tombol, karakter, dan background untuk aplikasi media pembelajaran

Pengabdian ini menghasilkan aplikasi media pembelajaran yang dibuat dengan menggunakan Macromedia Flash. Aplikasi media pembelajaran ini bisa dijalankan dengan menggunakan laptop atau PC. Media pembelajaran yang dibuat dengan Macromedia Flash ini bermanfaat untuk pembelajaran yang atraktif di kelas. Aplikasi bisa dibuat animatif sehingga bisa menarik perhatian siswa dalam proses belajar mengajar. Pembuatan aplikasi juga bisa ditambahkan suara, baik itu musik latar belakang atau pun suara guru yang sedang menerangkan. Selain itu, aplikasi ini juga bisa digunakan pada pembelajaran jarak jauh dengan program pendukung lainnya, seperti PowerPoint atau Word. Aplikasi ini juga bisa dibuat untuk tujuan latihan soal, kuis, atau pun tugas siswa. Dengan desain yang menarik seperti gim, guru bisa merancang soal berdasarkan materi yang sudah diberikan kepada siswa. Penggunaan aplikasi ini bisa sebagai pendalaman dan pembelajaran siswa baik di sekolah maupun di rumah.

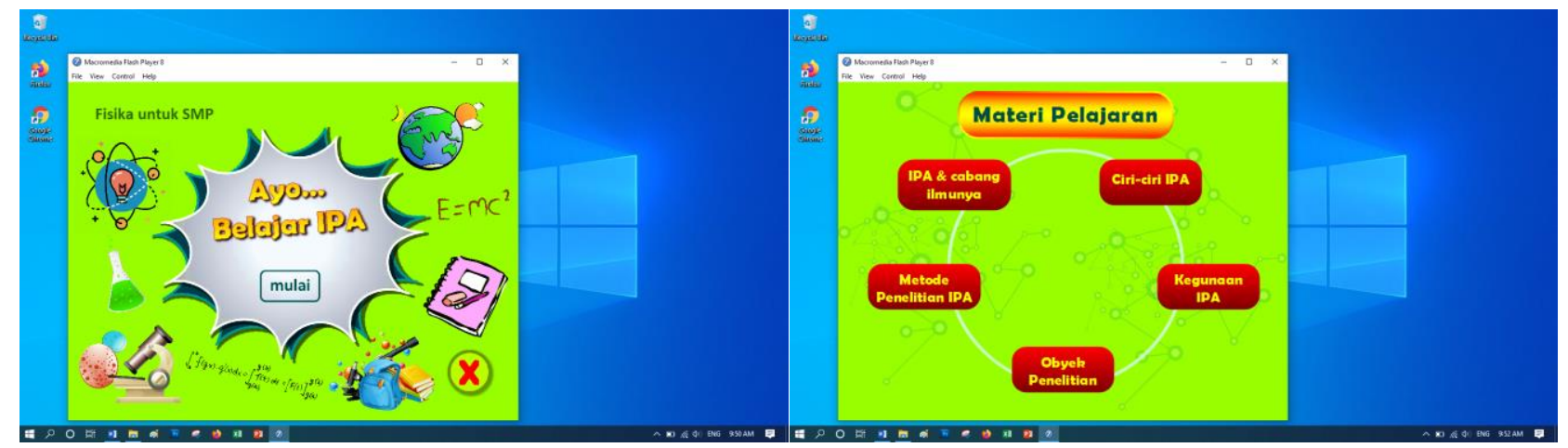

Gambar 5. Tampilan aplikasi media pembelajaran yang disusun dengan Macromedia Flash

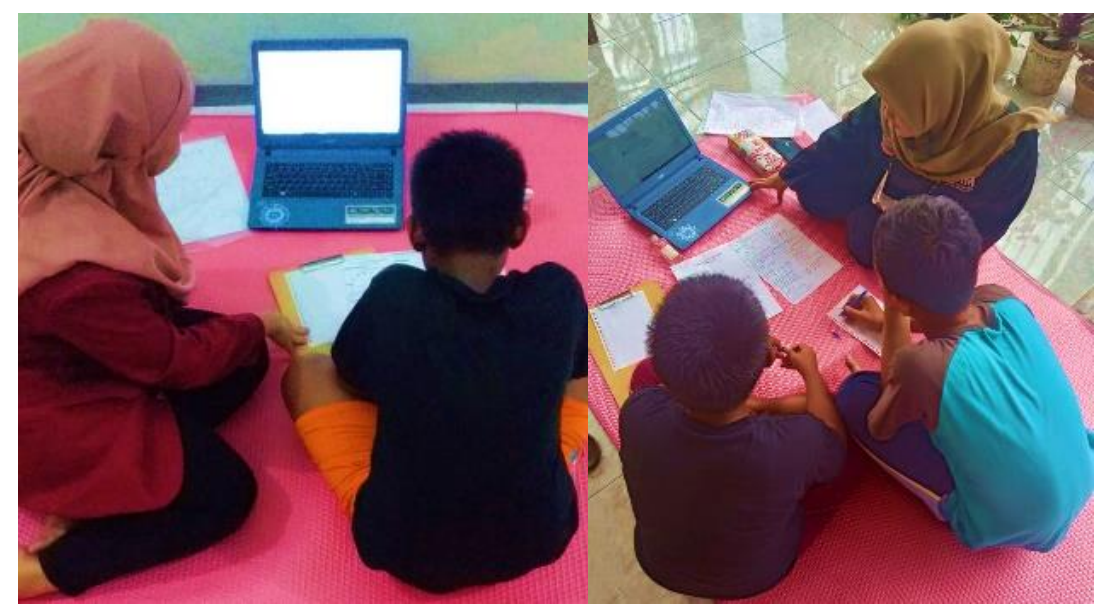

Gambar 6. Pengaplikasian media pembelajaran berbasis Macromedia Flash

\section{KESIMPULAN}

Dari pendampingan untuk pemanfaatan Macromedia Flash sebagai pembuat aplikasi media pembelajaran Fisika, dapat diambil kesimpulan bahwa guru harus mampu mengembangkan kreativitasnya dalam membuat media pembelajaran 
terutama yang melibatkan teknologi informasi dan komunikasi atau teknologi digital. Selain itu, guru juga perlu meningkatkan pengetahuan mereka dalam penerapan teknologi yang berhubungan dengan internet dan pembelajaran secara online. Pengembangan aplikasi media pembelajaran Fisika untuk SMP ini perlu dilakukan untuk menunjang pembelajaran yang aktif, kreatif, dan menyenangkan bagi siswa.

\section{UCAPAN TERIMA KASIH}

Ucapan terima kasih disampaikan kepada DPPM Universitas Muhammadiyah Malang yang telah memberikan memberikan dukungan dan dana atas tercapainya kegiatan pengabdian ini. Terima kasih kami ucapkan juga kepada SMP Muhammadiyah 6 Dau Malang yang ikut berpartisipasi dalam pelaksanaan kegiatan pengabdian sehingga media pembelajaran ini dapat dipublikasikan sebagai informasi dalam bidang pembelajaran.

\section{REFERENSI}

Budiarto, M.T., Wijayanti, P., Kurniasari, I. 2016. Kemampuan Mengembangkan Media Pembelajaran Berbasis ICT Bagi Guru-Guru MGMP SMP, SMA, dan SMK di Kabupaten Banyuwangi. Jurnal Abdi: Media Pengabdian kepada Masyarakat. 1(2):162-167. https://doi.org/10.26740/ja.v1n2.p162-167

Husnawati, A., Hartono, Masturi. 2019. Pengembangan Soal Higher Order Thinking Skill (HOTS) Fisika Kelas VIII SMP Materi Gerak Pada Benda. UPEJ : Unnes Physics Education Journal. 8(2):133-140. https://doi.org/10.15294/upej.v8i2.33320

Lubis, B.S., Siregar, E.F.S. 2020. Pelatihan dan Pendampingan Pembuatan Media Pembelajaran Interaktif Berbasis Macromedia Flash. Selaparang : Jurnal Pengabdian Masyarakat Berkelanjutan. 4(1)396-401. https://doi.org/10.31764/jpmb.v4i1.3143

Muthmainnah, Fajriana, Siska, D. 2017. Pemanfaatan Teknologi Informasi Untuk Meningkatkan Kualitas Pembelajaran. TECHSI : Jurnal Penelitian Teknik Informatika. 9(2):65-77. https://doi.org/10.29103/techsi.v9i2.214

Nugraheny, D., Wintolo, H., Kusumaningrum, A., Sudaryanto. 2018. Pendampingan Pembuatan Bahan Ajar Berbasis Multimedia Menggunakan Macromedia Flash Bagi Para Guru SD IT Salsabila Al Muthi'in, Yogyakarta. Kacanegara Jurnal Pengabdian pada Masyarakat. 1(1):23-28. http://dx.doi.org/10.28989/kacanegara.v1i1.266

Nurdewanto, B., Sonalitha, E., Rusdijanto, Sunarwan, A. 2018. Multimedia Learning Untuk Sekolah Dasar. Abdimas: Jurnal Pengabdian Masyarakat Universitas Merdeka Malang. 3(2):14-18. https://doi.org/10.26905/abdimas.v3i2.2587

Rahayu, S.W., Widyawati E. 2019. Pelatihan dan Pendampingan Pembuatan Media Pembelajaran Berbantu Macromedia Flash Bagi Guru SMPN 11 Tarakan Sebagai Salah Satu Upaya Peningkatan Inovasi Dalam Pembelajaran. JPMB (Jurnal Pengabdian Masyarakat Borneo). 2(2):25-28. https://doi.org/10.35334/jpmb.v2i2.519

Rahmi, M.S.M, Budiman, M.A., Widyaningrum, A. 2019. Pengembangan Media Pembelajaran Interaktif Macromedia Flash 8 Pada Pembelajaran Tematik Tema Pengalamanku. International Journal of Elementary Education. 3(2):178-185. http://dx.doi.org/10.23887/ijee.v3i2.18524

Rofiah, E., Aminah, N.S., Sunarno, W. 2018. Pengembangan Modul Pembelajaran Ipa Berbasis High Order Thinking Skill (HOTS) untuk Meningkatkan Kemampuan Berpikir Kritis Siswa Kelas VIII SMP/MTs. Inkuiri: Jurnal Pendidikan IPA. 7(2):285-296. https://doi.org/10.20961/inkuiri.v7i2.22992

Sarwinda, W., Meilana, S.F. 2019. Pengaruh Penggunaan Worksheet IPA Berorientasi HOTS Terhadap Hasil Belajar Kognitif Siswa SD Muhammadiyah 4 Dan 5 Jakarta. Jurnal Pendidikan Dasar. 10(1):77-84. https://doi.org/10.21009/10.21009/JPD.081 
Siahaan, S. 2015. Pemanfaatan Teknologi Informasi Dan Komunikasi Dalam Pembelajaran: Peluang, Tantangan, Dan Harapan. Jurnal Teknodik. 19(3):321-332. http://dx.doi.org/10.32550/teknodik.v19i3.173

Tekege, M. 2017. Pemanfaatan Teknologi Informasi Dan Komunikasi Dalam Pembelajaran SMA YPPGI Nabire. Jurnal Fateksa : Jurnal Teknologi dan Rekayasa. 2(1):40-52

Umbara, U., Rosyid, A., Setiawan, D.L. 2019. Pelatihan Pembuatan Media Pembelajaran Matematika Berbasis Flash Menggunakan Adobe Animate Bagi Guru SMP Di Kabupaten Kuningan. Jurnal Pengabdian Pada Masyarakat. 4(1):93-104. https://doi.org/10.30653/002.201941.84 